\title{
Teknik çeviri eğitiminde terminoloji - çeviri edinci ilişkisi: Örnek bir inceleme
}

İnönü KORKMAZ1

\begin{abstract}
APA: Korkmaz, İ. (2019). Teknik çeviri eğitiminde terminoloji - çeviri edinci ilişkisi: Örnek bir inceleme. RumeliDE Dil ve Edebiyat Araştırmalar Dergisi, (15), 328-341. DOI: 10.2900o/rumelide.580627
\end{abstract}

\section{$\ddot{O} \mathbf{z}$}

$\mathrm{Bu}$ çalışmanın amacı çeviribilimde son zamanlarda daha çok ilgi odağı olan teknik çeviri eğitimi bağlamında terminolojinin çeviri edincine ne tür bir etkisinin olduğunu irdelemektir. Bu amaçla Trakya Üniversitesi, Mütercim Tercümanlık Bölümü üçüncü sınıf öğrencilerinin zorunlu ders olarak aldıkları Teknik Çeviri dersinde bir vaka incelemesi gerçekleştirilmiştir. Bu bağlamda iki farklı otomobil markasına ait İngilizce kullanma kılavuzlarından alınan metin kesitlerindeki terimlerin çevirileri karşılaştırmalı olarak incelenmiştir. Bu doğrultuda öncelikle deney ve kontrol grubu olarak iki farklı öğrenci grubu oluşturulmuştur. Deney grubu 22 katılımcıdan, kontrol grubu ise 20 katılımcıdan oluşmaktadır. Kaynak metinler görece genel ve özel teknik terimler içermektedir. Deney grubuna çalışma süresince ilgili kaynak metinlerle içerdikleri terimler bakımından benzerlik gösteren metinler ve terim listeleri verilerek çevirmeleri istenmiştir. $\mathrm{Bu}$ durumun deney grubundaki katılımcıların alan edinci ve uzmanlık alanı edinci geliştirmelerine katkıda bulunacağı düşünülmüştür. Kontrol grubuna ise farklı alanlara ait metinler verilmiştir. Son olarak her iki gruptan bu çalışmada kullanılan kaynak metin kesitlerini çevirmeleri istenmiştir. Grupların çevirilerinin karşılaştırmalı incelemesinde ölçüt Toury’nin yeterlilik ve kabul edilebilirlik kavramlarıdır. Bu bağlamda “Otomotiv ve Hafif Araç Terimleri Sözlüğü”ndeki ilgili terimlere ait girdilerle de ayrıca karşılaştırılan çeviri birimlerin ne denli yeterli ya da kabul edilebilir oldukları değerlendirildiğinde deney grubunun daha çok kabul edilebilir çeviriler ortaya koyduğu anlaşılmıştır. $\mathrm{Bu}$ durum teknik çeviri eğitiminde terminoloji ya da terim çalışmalarının özellikle çeviri alt edinçlerinden uzmanlık alanı edinci, metin edinci ve konu edinci gibi edinçlere olumlu yönde katkısının bulunduğunu göstermektedir.

Anahtar kelimeler: Teknik çeviri eğitimi, çeviri edinci, terminoloji, çeviri alt-edinçleri.

\section{Relationship between terminology - translation competence in translator training: A case study}

\begin{abstract}
The aim of this study is to examine the effect of terminology on translation competence in the context of teaching of technical translation which has been the focus of attention more recently in translation studies. For this purpose, a case study was carried out in the Technical Translation course of the third year graduates of the Department of Translation and Interpreting at Trakya University. In this context, translations of the terms in the text sections taken from the English user guides of two separate car brands have been examined comparatively. In this direction, two different student groups have been formed as experimental and control groups. The experimental group had 22 participants and the control group had 20 participants. Source texts consist of relatively general and
\end{abstract}

1 Dr. Öğr. Üyesi, Trakya Üniversitesi, Edebiyat Fakültesi, Mütercim-Tercümanlık Bölümü (Edirne, Türkiye), inonukorkmaz@trakya.edu.tr, ORCID ID: 000o-0001-5601-1997 [Makale kayit tarihi: 21.05.2019-kabul tarihi: 20.06.2019; DOI: 10.29000/rumelide.580627] 
specific technical terms. The experimental group has been assigned to translate the texts and term lists which resemble to the source texts due to the terms they contain. It is considered that this would aid the participants in the experimental group to develop their specialized field competence, text competence and subject competence. The control group received texts from different fields. Finally, both groups have been assigned to translate the same source text sections used in this study. The criteria for the comparison of the different groups' translations have been the terms of Toury's acceptability and adequacy. In this context, it has been understood that the experimental group has performed more acceptable translations rather than the control group when the translation units have been checked via the "Dictionary of Automative and Light Vehicle Terms". This possibly demonstrates that the terminology or term studies in technical translator training could contribute specifically to the development of specialized field competence, text competence and field competence in translation trainees.

Keywords: Teaching technical translation, translation competence, terminology, translation subcompetences.

\section{Giriș}

Çeviri eylemini en genel anlamda iki farklı kültür arasında iletişim aracı biçiminde değerlendirecek olursak söz konusu iletişimin teknik metinler gibi kendine has terimlerin varlığının hissedildiği durumlarda terminoloji bilgisine ihtiyaç duyulması kaçınılmazdır. Ancak tek başına terminoloji bilgisinin yeterli olup olmayacağı tartışlabilir. Bunun yanı sıra çevirinin salt bilgi ve düşüncelerin mekanik bir biçimde aktarımı olarak sınırlandırılamaz olması her dil bilen bireyin çevirmen niteliklerine sahip olamayacağını da destekler. Öyle ki çevirmenlerde salt dil edincinin değil ayrıca çeviri edincinin de belirli bir düzeyde gelişmiş olması beklenmektedir. Bu bakımdan öncelikle teknik çeviri, terminoloji ve çeviri edinci gibi kavramların çeviribilimde temel olarak nasıl ele alındığını irdelemek bu üç kavramın birbirleri ile olan ilişkisini anlamamıza yardımcı olabilir. Çeviribilim alanında kısa bir süre öncesine değin teknik çeviri, bilimsel çeviri ile birlikte, üzerinde çok sayıda araştırma yapılmamasına karşın dünya çapında çeviri piyasasında hem çevrilen metinlerin hacmi hem de bu çeviriler için ödenen ücret bakımından diğer çevirileri geride bırakan bir çeviri türü olarak görülmekte idi (Aixela, 2004). Günümüzde ise teknik çeviri üzerine görece daha çok sayıda incelemenin yapılmakta olduğuna tanıklık etmekteyiz. Bunun nedenlerinin başında teknolojinin hızlı gelişiminin sonucu olarak teknolojiyle ilgili metinlerin çevirisinde yaşanan artış gelebilir. Aslında gündelik hayatımızın hemen her anında görece daha çok teknoloji ile içi içe olmamız da kullandığımız teknolojik ürünlere ait dokümantasyonun çeviri sürecinin önemini de artırmaktadır.

Teknik çeviriyi tanımlama çabasına giriştiğimizde öncelikle teknik çevirinin sıkça bilimsel çeviri ile bir arada anıldığına ve hatta bu iki kavramın kimi zaman birbirlerinin yerini alan kavramlar olduğuna şahit olmaktayız. Bilimsel ve Teknik çeviri üzerine yaptığı kapsamlı bir çalışmada Byrne bu görüşün karşısında durmaktadır ve her iki kavramın birbirlerinden bağımsız olarak ele alınmaları gerektiğini vurgulamaktadır (2006, s. 7). Byrne görüşünü desteklemek üzere şu örneği sunmaktadır; bir elektrik motorunun nasıl kurulacağına ve kullanılacağına ilişkin bilgi veren kılavuz teknik metin olarak adlandırılırken elektromotor güç ve iletkenler üzerinden geçen akımın etkileri üzerine yazılan makale ise bilimsel metin olarak nitelendirilmektedir (a.g.e., s.8). Dolayısıyla söz konusu kılavuz metninin çevirisi teknik çeviri diğer yandan ise makalenin çevirisi de bilimsel çeviri kapsamına girecektir. 
Ayrıca teknik çevirilerin malzemesi olan teknik metinler bir bilim dalında üretilen bilgi birikimi sonucu ortaya çıkarılan ürün ya da malzemelerin gündelik hayatta uygulama alanında insanların hizmetinde nasıl kullanılacağını hedef almaktadır (Korkmaz, 2017, s. 27). Bu bağlamda teknik çeviriyi görece bilginin uygulamaya yönelik dağılımı diğer yandan bilimsel çeviriyi de kuramsal ya da teorik anlamda dağılımı ile ilişkilendirmek daha doğru olacaktır. Ancak sırf teknik ile nitelendirildiği için bu çeviriyi sadece teknoloji ve/ya bilim ile ilgili bilginin aktarılmasına yönelik olarak görmek de yanıltıcı olabilir. Hervey ve Higgins'in de vurguladığı gibi (2002, s. 172) aslında her uzmanlık alanı içinde o alana özgü teknik terimler ve o alanda üretilen metinlerin kendilerine has ayırt edici özelliklerini bulmak mümkündür. Bu bağlamda teknik kavramını daha çok uzmanlık bilgisinden yoksun okurlar için anlaşılması zor ve erişimi görece kolay olmayan bilgi olarak değerlendirmek gerekir.

Teknik çeviri tanımının yanı sıra Jody Byrne’ın ayrıca değindiği bir başka konu ise teknik çevirinin maruz kaldığı "teknik çeviri sadece ekonomi, hukuk, ticaret gibi belli başh uzmanlk alanlartmı içerdiği" ve "teknik çevirinin tamamen terminoloji ile ilgili olduğu" gibi bir takım önyargılardır (a.g.e., 3). Burada teknik çeviri ile terminoloji arasında kurulmaya çalışılan bağın hem teknik çeviri hem de kendi başına bir disiplin sayılabilecek terim çalışmaları adına küçük düşürücü bir yanı bulunmaktadır. Bir yanda terminoloji alanı sadece teknik çeviriye atfedilerek görece dar bir çerçeve içine yerleştirme riski bulunmaktadır. Öyle ki herhangi bir alanda kuramsal bilgi ve tecrübe birikiminin ürünü olan bilimsel metinler ister istemez bu çerçevenin dışında kalacaktır. Diğer yanda ise teknik çeviriyi salt terminoloji ile bağdaştırmak bir bakıma teknik çeviriyi görece daha mekanik bir işleme indirgeyerek küçük düşürme cüretinde bulunmak demektir. Öyleyse hangi zorlukta olursa olsun herhangi bir teknik metni surf terimlerinin karşıllklarının elde edilmesiyle çevirisi hiç zorlanmadan her çevirmen tarafından gerçekleştirilebileceği gibi temelsiz bir yargı da doğru kabul edilebilirdi.

Özellikle bu önyargı hakkında Bryne muhalif bir tavır takınmakta ve terminolojiyi teknik çevirinin iletmek istediği fikir ya da düşünceleri iletmede kullanılan bir araç olarak gördüğünü bildirmektedir (a.g.e., 3). Bununla paralel olarak Peter Newmark (1988) terminolojiyi aslında teknik çeviriyi diğer çevirilerden ayırt etme aracı olarak değerlendirir. Dahası herhangi bir teknik metindeki terminoloji yoğunluğunun aslında \%5 -10 arasında değişmekte olduğunun da altını çizmektedir.

Dahası terminoloji salt teknik çevirinin bir parçası olarak görülemez. Bu bağlamda kabaca birçok alanda teknik ve genel terimlerin varlığından bile söz etmek mümkündür. Hele ki çeviri ile terminoloji söz konusu olduğunda Sager’in de (2001, s. 259) belirttiği gibi bu iki kavram aslında iki farklı dilbilimsel ve bilişsel düzlemde işleyen ve dilin farklı alanlarına odaklanan disiplindirler. Sager, terminolojiyi bir dilde herhangi bir alanda üretilen bir metnin içindeki sözcük ya da terimlerden bir kaynak dizin oluşturmayı ve bunları da aynı alanda ileride kullanmak üzere düzenlemeyi hedefleyen bir disiplin olarak görür. $\mathrm{Bu}$ bakımdan terminolojinin sadece teknik çeviriye özgülüğünden ya da teknik çevirinin de salt terim aktarımından ibaret olduğundan bahsetmek mümkün değildir.

Çalışmamızda ön plana çıkan üçüncü kavram çeviri edincidir. Öncelikle edinç kavramını açıklayarak başlayalım. Edinç en genel anlamında Türk Dil Kurumu tarafından basılan Türkçe sözlügünde "Edinilen şey veya şeyler, müktesebat" olarak tanımlanmaktadır (TDK, 2011, s. 756). Diğer yandan edinç, Kamile İmer, Ahmet Kocaman ve A. Sumru Özsoy’un hazırladığı Dilbilim Sözlüğ̈̈’nde;

"Üretici Dilbilgisi Kuramında, bir dilde daha önce hiç üretilmemiş tümcelerin konuşucu dinleyiciler tarafindan üretilip yorumlanabilmelerini açlklayan içsel dil bilgisi, dil yetisi” (İmer, Kocaman, \& Özsoy, 2013, s. 113) 
olarak tanımlanmaktadır. Ülkemizde dilbilim alanında önemli isimlerden biri olan Berke Vardar tarafından hazırlanan sözlükte ise edincin tanımı şu şekildedir.

“(Alm. Kompetenz, Fn. Competence, İng. Competence). Üretici dönüşümsel dilbilgisinde konuşucudinleyicilerin edinmiş oldukları, daha önce hiç duyup söylemedikleri tümceleri de kapsayan sonsuz sayıda tümce oluşturup anlamaların sağlayan dilsel bilgi.” (Vardar, 2002, s. 89)

Edincin genel anlamını bir yana bırakıp dilbilimsel anlamına odaklanacak olursak yukarıdaki her iki tanımlama da çeviri bakış açısı ile birleştirildiğinde tek başlarına yetersiz kalacaktır. Öyle ki bu iki tanımlama konuşucu-dinleyicinin daha çok yaratıcı yönünü ön plana çıkarır gibi görünmektedir. Bunun nedeni daha önce hiç üretilmeyeni üretmek ya da daha önce hiç duyulmamış olanı yorumlamanın içsel bir kaynaktan yararlanmak zorunda kaldığını ima etmesinde yatabilir.

Çeviri penceresinden edinç kavramına bakıldığında ise daha önceleri edincin yerine tercih edildiği varsayılan 'yeti', 'beceri' ve 'yetenek' kavramlarını da sorgulayan Durukan ve Çelikay bahsi geçen kavramların çeviri edincini açıklamada tam anlamıyla başarılı olamadıklarını belirtmektedir (2018, s. 166). Bu görüşle paralel olarak çeviri edinci söz konusu olduğunda Akalın (2016, s. 60) 'edinç' ile 'beceri' kavramları arasında aslında bir hiyerarşik ilişki bulunduğunu edincin daha genel ve kapsayıcı bir anlam taşırken becerinin salt çeviri etkinliğinde ortaya çıarılan yeteneklerin her biri olarak tanımlanabildiğini ifade etmektedir. Bu görüş çeviri edincinin tek bir durum ya da koşulda ortaya çıkan yetenek veyahut beceriden ibaret olmadığını aksine birçok durum ya da koşul karşısında ortaya konan alt yetenekler ve becerilerin, dolayısıyla alt edinçlerin toplamına karşılık geldiğini desteklemektedir. Bir başka deyişle, çeviri edinci salt dilsel bir iletişim becerisinin ya da kültürel bir bilgi birikimi elde edebilme yetisi anlamına gelmez. Dahası bu ve buna benzer diğer birikim ve davranışsal edimlerin toplamıdır. $\mathrm{Bu}$ doğrultuda iki önemli çalışma grubunun edinç tanımı üzerine çalışmaları önemlidir;

Çeviri edincinin tanımlanmasına ve alt edinç türlerinin belirlenmesine yönelik çalışmalarında PACTE ${ }^{2}$ grubu kapsamlı bir edinç modeli ortaya çıarmıştır (2000). Buna göre edincin alt bileşenleri şöyle siralanmaktadır;

a) İki dilli iletişimsel edinç genellikle iki dil arasında iletişim kurmaya yardımcı olan becerileri kapsar ve çevirmenler için kaynak dilin anlaşılması ve hedef dilde üretim olarak gruplandırılabilir.

b) Dil dışı edinç genel dünya bilgisi ve uzmanlık alanı bilgisini kapsar.

c) Araçsal edinç her türden belgelendirme araçlarının ve yeni teknolojilerin kullanımı, piyasa hakkında bilgi, iş etiğine uygun davranabilme yetisi gibi alanları içerir.

d) Psiko-Fizyolojik edinç ise en temelde okuma ve yazma için gerekli psikomotor beceriler, belleğinde tutabilme, dikkatini uzun süre dağıtmadan durabilme, kaynak metne ya da kaynak metindeki bilgiye karşı entelektüel ilgi ya da merak duyabilme, kendine güvenebilme gibi becerileri içerir.

e) Aktarım edinci ise diğerlerinin tümünü birleştiren merkezi edinçtir. Kaynak metni anlayıp erek dilde bunu yeniden ifade edip üretme becerisini kapsar.

PACTE: Process in the Acquisition of Translation Competence and Evaluation (Çeviri Edinci Kazanımı ve Değerlendirilmesi Süreci) 
f) Stratejik edinç ise çeviri sürecinde karşılaşılan sorunları çözmek için kullanılan tüm bilinçli ya da bilinç dışı, sözlü ya da sözsüz bireysel işlemleri içerir (PACTE Research Group, 2000).

Son olarak European Master's in Translation ${ }^{3}$ (EMT) tarafından geliştirilen çeviri edinci modeli ise dil edinci, bilgi araştırma edinci, konu edinci, teknolojik edinç ve çeviri hizmeti sağlama edinci başlıkları altında alt edinçlere bölümlendirilmiştir (Acar \& Korkmaz, 2017).

Mevcut çalışma ise çeviri edincini genel anlamından soyutlayıp daha öznel bir bağlam içinde ele almakta olup teknik çeviride terminoloji ya da terim bilgisinin bu edinç ve onun ilgili alt edinci üzerinde ne gibi etkilerinin olduğunu irdelemektedir. Bu doğrultuda çeviri edinci hakkındaki tanımlamalardan ve modellerdeki alt edinçlerden yola çıkarak teknik çeviri kapsamında örnek iki metnin çevirmen adayları tarafından çevirisinde terim bilgisinin ya da terminolojinin çevirilere ne yönde etkide bulunduğu incelenecektir. Bu bağlamda yukarıda değinilen çeviri alt edinçlerinden dil dışı ya da uzmanlık alanı bilgisi, metin bilgisi ve konu bilgisi olarak nitelendirilen alt edinçler ele alınacaktır.

\section{Yöntem}

Çalışmanın bütüncesini oluşturmak üzere iki farklı otomobil üreticisine ait İngilizce kullanma kılavuzlarından birer metin seçilmiş olup iki farklı öğrenci grubunun gerçekleştirdiği çeviriler karşılaştırılmıştır. Öğrenci grupları aynı eğitim seviyesinde olup (Trakya Üniversitesi, Mütercim Tercümanlık İngilizce Lisans Programı 3. sınıf öğrencileri) deney grubu ve kontrol grubu olarak ikiye ayrılmıştır. Deney grubu ile kontrol grubu aynı lisans programında öğrenim gören iki ayrı şube öğrencilerinden oluşmaktadır (A ve B şubeleri). İki gruba haftanın farklı günlerinde katıldıkları Teknik Çeviri dersinde çalışmanın veri toplama süreci boyunca farklı görevler verilmiştir. A şubesinin öğrencileri deney grubu olarak kabul edilmiş olup toplam 22 katılımcıdan oluşmaktadır. Deney grubuna dört hafta boyunca kaynak metinlere dilsel özellikleri ve içerdikleri terimler bakımından benzerlik gösteren kllavuz metinler verilip öğrencilerden dersin sorumlusunun gözetimi ve kontrolü altında çevirmeleri istenmiştir. Ayrıca konu ile ilgili olarak farklı kelime ve terim listeleri içeren basılı ve elektronik kaynaklar öğrencilerle paylaşılmıştır. Diğer yandan B şubesi öğrencileri ise kontrol grubu olarak tayin edilmiştir toplam 20 katılımcıdan oluşmaktadır. Ayrıca kontrol grubuna diğer gruptan farklı olarak belirlenen dört hafta süresince mutfak aletleri ve ev eğlence sistemlerine ait kılavuz metinler verilerek bunların çevirileri istenmiştir. Böylece dersin olağan gidişatını bozmayacak biçimde her iki grup öğrencilerine de dersin içeriğine uygun ders materyalleri sunularak alanları farklı ancak biçim bakımından benzer metinleri inceleme firsatı verilmiş oldu. Ayrıca terim bilgisi çalışması yapılan grup ile bu grubun çalışma kapsamında gerçekleştirecekleri çeviriler arasındaki gerçekleşmesi beklenen farklılıklar terminolojinin teknik çeviri bağlamında çeviri edinci edinilmesine katkıda bulunup bulunmadığına dair somut veriler sunabilir.

Dört haftalık sürenin sonunda her iki gruptan da iki farklı otomobil kullanma kılavuzundan alınmıştır birer adet metin kesitinin çevirisi istenmiştir. Kaynak metinler içerisinde hem genel hem de özel alan bilgisi gerektirebilecek terim, sözcük ve söz grupları bulunmaktadır. İncelemek üzere seçilen terim, sözcük ya da söz grubu sayısı her iki metin için de 10 olup toplamda 20 terim (söz konusu metinler sözcük sayısı bakımından birbirlerine yakın büyüklükte olup içerdikleri özel alan terimleri tesadüfi olarak eşit çıkmıştır), sözcük ya da söz grubu incelenecektir. KM1 ve KM2 olarak nitelendirilen kaynak 
metinlerden alıntılanan metin kesitlerinin tamamı aşağıda kaynak metin künye bilgileri ile birlikte verilmiştir.

Kaynak Metin 1(KM1): 2013 Model BMW1 Series Manual4.

"Technology for driving comfort and safety

\section{Park Distance Control PDC}

The concept

The PDC assists you with maneuvering in tight parking spaces. Acoustic signals and a visual indicator warn you of the presence of an object behind your vehicle. Four ultrasonic sensors in the bumper measure the distance.

These sensors have a range of approx. $6.5 \mathrm{ft} / 2 \mathrm{~m}$. However, an acoustic warning does not sound until an object is approx. $2 \mathrm{ft} / 6 \mathrm{om}$ from the corner sensors, or approx. $5 \mathrm{ft} / 1.5 \mathrm{O} \mathrm{m}$ from the center sensors.

$P D C$ is a parking aid that can indicate objects when they are approached slowly, as is usually the case when parking. Avoid approaching an object at high speed; otherwise, physical circumstances may lead to the system warning being issued too late.

Switching on automatically

With the engine running or the ignition switched on, the system is activated after approx. second when you engage reverse gear or move the automatic transmission selector lever to position R. Wait this short period before driving."

Kaynak Metin 2 (KM2): 2013 Model Volvo S6o Owner's Manual5

“Airbags - SRS

If this light comes on while the vehicle is being driven, or remains on for longer than approximately 10 seconds after the vehicle has been started, the SRS system's diagnostic functions have detected a fault in a seat belt lock or pretensioner, a front airbag, side impact airbag, and/or an inflatable curtain. Have the system(s) inspected by a trained and qualified Volvo service technician as soon as possible. See page 22 for more information about the airbag system.

\section{Seat belt reminder}

This symbol comes on for approximately 6 seconds if the driver has not fastened his or her seat belt.

\section{Generator not charging}

This symbol comes on during driving if a fault has occurred in the electrical system. Contact an authorized Volvo workshop."

İncelenen terimlerin deney ve kontrol grupları tarafından gerçekleştirilen çevirileri TDK tarafından basılan "Otomotiv ve Hafif Araç Terimleri Sözlüğü”ndeki (Yüce, 2013) terimlere ait açıklamalar ile karşılaştırılacaktır. Böylece öğrencilerin çevirilerindeki ilgili terim ya da sözcüklerin Türkçe basılı bir terim sözlüğü referans alarak teyit edilmesi uygun görülmüştür. Ayrıca kaynak metin terimleri ile çeviri metin terimleri Toury'nin erek odaklı yaklaşımı çerçevesinde karşılaştırılacaktır. Toury'nin ortaya koyduğu yeterlilik ve kabuk edilebilirlik kavramları çevirilerin erek ve kaynak dil kutbuna yakınlıklarına göre belirlenmektedir (Toury, 2008). Karşılaştırma sonucunda çeviri metinlerdeki erek kutba yakın terim / sözcük birimleri kabul edilebilir çeviri, kaynak kutba yakın olanları ise yeterli çeviri olarak nitelendirilecektir.

\footnotetext{
4 BMW firmasının 2012'den bu yana çevrimiçi ortamda müşterilerinin açık erşimine sunduğu kılavuz metinler arasında bulunmaktadır. Cevrimiçi erișim için bkz. http://www.bavarianmw.com/guide-4441.html

'Volvo Car USA Support' müşteri yardım internet sayfasından indirilmiştir. Çevrimiçi erişim için bkz. https://volvornt.harte-hanks.com/manuals/2013/2013-Volvo-S6o-Owners-Manual.pdf
} 


\section{Bulgular}

Kaynak metinlerden seçilen terimler ve öğrencilerin çevirilerinde saptanan karşılıkları aşağıdaki tablolarda her bir kaynak metin için ayrı ayrı verilmektedir (bkz. Tablo 1 ve Tablo 2). Öğrenci gruplarının çeviri metinlerinde tespit edilen her bir farklı çeviri sayısı ilgili terimlerin yanında sayı ile belirtilmiş olup terimlerin karşılaştırıldıkları terim sözlügündeki karşılıklarına benzerlikleri daha sonra grafik olarak sunulup çalışmanın sonuç bölümünde ayrıntılı olarak yorumlanacaktır. Bulguların incelenmesi deney (A) ve kontrol (B) gruplarının çevirilerinde sundukları terimlerin Yüce'nin hazırladığı sözlükteki girdiler ile ne derece örtüştüğü bu grafiklerde açlkça görülebilir.

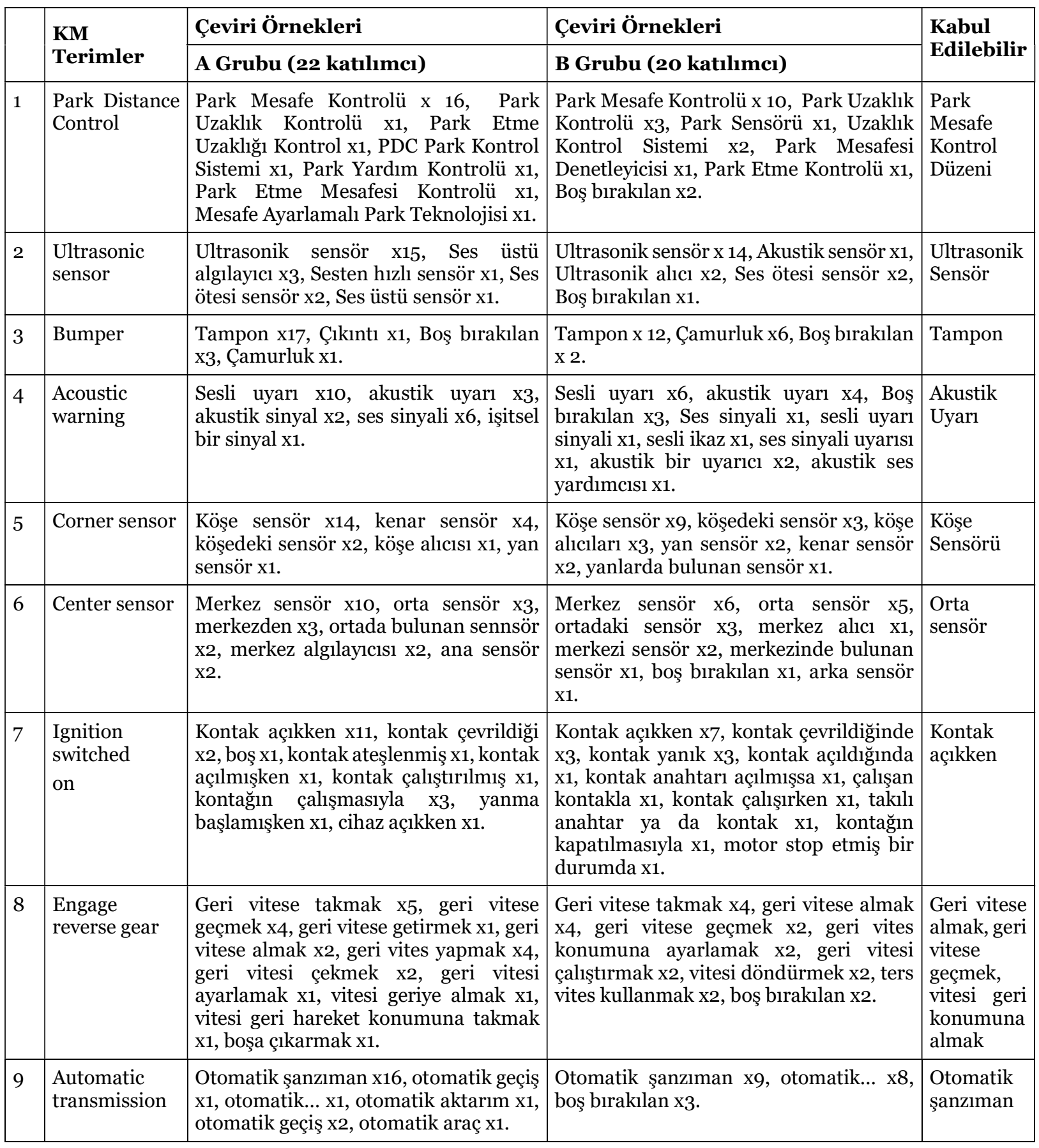




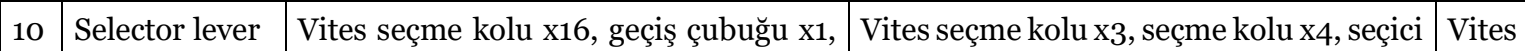
transistör kolu x1, vites x1, vites kolu kolu x7, selektör kolu x3, vites paneli x1, seçme kolu \begin{tabular}{l|l} 
selektörü x1, selektör x1, levye x1. & vites x2.
\end{tabular}

Tablo 1: Kaynak Metin 1'den seçilen terimler ile A ve B Gruplarının çevirilerinde tespit edilen karşılıkları ve TDK terim sözlüğü referans alınarak belirlenen kabul edilebilir terim önerileri.

Kaynak Metin 1'deki terimlerin ilki, 'Park Distance Control', ayrıca metnin bu kesitinin alt başlığı niteliğinde olup A grubuna ait 22 metnin 16'sında TDK terim sözlüğündeki girdiye yakın olarak "Park Mesafesi Kontrolü” olarak karşılık bulmuştur. Buna karşlık B grubunda sadece 10 kez aynı ifade ile karşılaşılmıştır.

KM1'deki ikinci terim "Ultrasonic sensor" olup görece genel bir terimdir. Çünkü bu terim ayrıca insan kulağının işitemeyeceği kadar yüksek frekanslı ses dalgalarının yayılması prensibine dayanan bir teknolojinin kullanımına işaret eden elektronik bir aygıtın ismidir. Bu bakımdan sadece otomobillere özgü bir kullanımdan çok örneğin alışveriş merkezlerinin otomatik kapıları ya da ev ve işyerlerinde kullanılan hırsız alarmları gibi birçok kullanım alanına sahiptirler. Terim Türkçe kaynaklara doğrudan aktarım yoluyla girmiş bir terim olduğundan hem A hem de B grubundaki kabul edilebilir terim sayısı birbirine yakındır; A grubunda 15, B grubunda 14.

Üçüncü terim "Bumper" görece kafa karıştırıcı bir terimdir. Terim ile aslında ifade edilmek istenen motorlu araçların ön ve arka taraflarında bulunan kimi zaman plastik kimi zaman metal alaşımlı koruma parçalarıdır. Türkçede buna karşılık gelen ifade "tampon" olup kimi çevrimiçi sözlüklerde yanlış bir biçimde "çamurluk" ifadesi ile karşlanmaktadır'. Aslen "çamurluk" ile kastedilen, motorlu taşıtların tekerleklerinin etrafındaki kaporta kesiti olup İngilizcede karşllğı "fender" dir. Bu durum muhtemelen B grubunda $12 \mathrm{kez}$ "tampon" ifadesinin yanı sıra $6 \mathrm{kez}$ "çamurluk" ifadesi ile karşılaşılmasını açıklayabilir. A grubunda ise kabul edilebilir "tampon” ifadesi ile 17 kez karşılaşılmıştır.

Dördüncü (acouistic warning), beşinci (corner sensor) ve altıncı (center sensor) terimler yine genel terimler arasında sayılabilir. A grubunda kabul edilebilir çeviri örneklerinin sayısı sırasıyla 13, 14 ve 13 iken B grubundaki örneklerin sayıları yine sırasıyla 10, 9 ve 11'dir. Katılımcı sayısının kabul edilebilir çevirilere oranı neredeyse birbirine yakın olduğu görülmektedir.

İncelenen yedinci kaynak metin birimi "ignition switched on" biçiminde bir tümce olup otomobilin kontak anahtarının hangi durumda olduğuna işaret etmektedir. A grubunda bu ifade $11 \mathrm{kez}$ kabul edilebilir bir biçimde çevrilmiş olup katılımcı sayısına göre \%50 gibi bir başarı oranına sahiptir. B grubunda ise kabul edilebilir çeviri örneği sayısı 7 olup başarı yüzdesi \%35’tir.

Buna benzer biçimde KM1'de incelenen sekizinci birim bir tümcedir; "Engage reverse gear". A grubunda bu ifade için verilen kabul edilebilir çeviri sayısı 11 olup yine yarı yarıya bir başarı oranına işaret etmektedir. Bu sefer B grubunda da aynı oranda bir başarıya ulaşıldığı gözlemlenmiştir (10 adet kabul edilebilir çeviri birimi).

Dokuzuncu kaynak metin birimi “automatic transmission” için A grubunda oldukça yüksek bir kabul edilebilir çeviri sayısına (16 kez) ulaşılmışken B grubunda ise bu sayı sadece 9'da kalmıştır.

6 Çevrimiçi ‘tureng’ sözlüğündeki “bumper” karşıllı̆̆ için bkz. https://tureng.com/tr/turkce-ingilizce/bumper 
Bu bölümde incelenen son terim örneği "selector lever" olup A grubunun çevirilerinde yine 16 kez kabul edilebilir terimlerle karşılaşılmış, diğer yandan B grubunda kabul edilebilir çeviri terim sayısı 3 gibi oldukça düşük bir seviyede kalmıştır.

Toury'nin yeterlilik kavramı doğrultusunda çeviri metinlerde yeterli çeviri olarak nitelendirebileceğimiz farklı çeviri önerileri de mevcuttur (yeterli çeviri olarak nitelendirilen terimler tablolarda A ve B grubuna ait çeviri örneklerinin Tabloların son sütununda Kabul edilebilir olarak listelenen çeviri örnekleri ile örtüşmeyen örneklerdir);

Birinci terim için "Park sensörü" ya da "PDC Park Kontrol Sistemi” görece kaynak kutba daha yakın olup yeterli çeviri olarak nitelendirilebilir. İkinci terim için "Akustik Sensör", dördüncü terim için "ses sinyali" ya da "sesli uyarı", beşinci terim için "yan sensör" ya da "kenar sensör", yedinci terim için "kontak çalıştırılmış" ya da "kontak çalışırken", sekizinci terim için "geri vites yapmak", dokuzuncu terim için "otomatik aktarım" ve onuncu terim için de sadece "vites" ya da "vites kolu" da yeterli çeviri olarak sayılabilir (bkz. Tablo 1).

\begin{tabular}{|c|c|c|c|c|}
\hline & \multirow{2}{*}{ Terimler } & Çeviri Örnekleri & Çeviri Örnekleri & \multirow{2}{*}{$\begin{array}{l}\text { Kabul } \\
\text { Edilebilir }\end{array}$} \\
\hline & & A Grubu (22 katılımci) & B Grubu (2o katılımeı) & \\
\hline 1 & Airbags & Hava yastığı x6, hava yastıkları x16. & Hava yastığı x8, Hava yastıkları x12. & Hava yastıkları \\
\hline 2 & SRS & $\begin{array}{l}\text { SRS Ek güvenlik sistemi x16, Ek gergi } \\
\text { sistemi x5, Boş x1. }\end{array}$ & $\begin{array}{l}\text { Gergi sistemleri x12, SRS İlave } \\
\text { kısıtlama sistemi x6, Boş x2. }\end{array}$ & $\begin{array}{l}\text { Tamamlayıcı } \\
\text { koruma düzeni }\end{array}$ \\
\hline 3 & $\begin{array}{l}\text { Diagnostic } \\
\text { function }\end{array}$ & $\begin{array}{l}\text { Tanı işlevi x11, Teşhissel fonksiyon x1, } \\
\text { Teşhis fonksiyonu x5, teşhis işlevi x1, } \\
\text { Tanı fonksiyonu x2, Boş bırakılan x2, }\end{array}$ & $\begin{array}{l}\text { Hata ayılama sistemi x3, Teşhis } \\
\text { işlevi x5, Tanımlama cihazı x1, tespit } \\
\text { özeliği x1, sorun belirleme } \\
\text { fonksiyonu x2, teşhis sistemi x2, } \\
\text { tanılayıcı işlevi x2, boş bırakılan x3, } \\
\text { arıza işlevi x1. }\end{array}$ & $\begin{array}{l}\text { Arıza belirleme } \\
\text { işlevi }\end{array}$ \\
\hline 4 & Seat belt lock & $\begin{array}{l}\text { Emniyet kemeri kilidi x16, Emniyet } \\
\text { kemeri yuvası x1, Boş bıraklan x1, } \\
\text { Emniyet kemeri tokası x1, Emniyet } \\
\text { kemeri x3. }\end{array}$ & $\begin{array}{l}\text { Emniyet kemeri kilidi x15, Boş } \\
\text { bırakılan x2, hava yastığ kilidi x1, } \\
\text { emniyet kemerinde x2. }\end{array}$ & $\begin{array}{l}\text { Emniyet } \\
\text { kemeri kilidi }\end{array}$ \\
\hline 5 & Pretensioner & $\begin{array}{l}\text { Emniyet kemeri gergisi x8, gergi x4, } \\
\text { pretensiyoner x3, gerilim engelleyici x1, } \\
\text { çıkış noktası x1, engelleyici x1, gerilim } \\
\text { sistemi x1, boş bırakılan x1gösterge x1, } \\
\text { çekeceğiniz yer x1. }\end{array}$ & $\begin{array}{l}\text { Kemer gergisi x5, gergi sistemi x2, } \\
\text { pretensiyoner x5, toka x2, ön gerilim } \\
\text { x2, gösterici x2, boş birakılan x1, } \\
\text { gerginlik x1. }\end{array}$ & Ön gergi düzeni \\
\hline 6 & Front airbag & Ön hava yastığ1 x21, hava yastığı x1. & $\begin{array}{l}\text { Ön hava yastığ x18, boş bırakılan x1, } \\
\text { ön taraf hava yastığı x1. }\end{array}$ & $\begin{array}{l}\text { Yolcu hava } \\
\text { yastığ }\end{array}$ \\
\hline 7 & $\begin{array}{l}\text { Side impact } \\
\text { airbag }\end{array}$ & $\begin{array}{l}\text { Yan hava yastığ x13, yan koltuk hava } \\
\text { yastığı x1, yan çarpışma hava yastığ x3, } \\
\text { yanlardaki hava yastığ } 12 \text {, boş bırakılan } \\
\text { x1, yan impakt hava yastığ x1, hava } \\
\text { yastığının yan etkisi x1. }\end{array}$ & 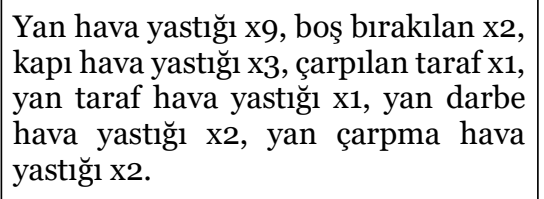 & $\begin{array}{l}\text { Yan darbe hava } \\
\text { yastığg }\end{array}$ \\
\hline 8 & $\begin{array}{l}\text { Inflatable } \\
\text { curtain }\end{array}$ & $\begin{array}{l}\text { Perde hava yastığ } 1 \text { x14, şişme perde x2, } \\
\text { şişirilebilir perde } \mathrm{x} 4 \text {, şişirilebilir hava } \\
\text { perdesi x1, cam hava yastığ } 1 \text { x1. }\end{array}$ & $\begin{array}{l}\text { Perde hava yastığ } \mathrm{x} 2 \text {, boş bırakılan } \\
\text { x6, şişirilebilir hava yastığ } 1 \text { x1, } \\
\text { şişebilen perde x6, şişme perde x2, } \\
\text { cam hava yastığ } 1 \text { x1, perde kısmı x2. }\end{array}$ & $\begin{array}{l}\text { Perde } \\
\text { yastığ } 1\end{array}$ \\
\hline
\end{tabular}




\begin{tabular}{|c|c|c|c|c|}
\hline 9 & $\begin{array}{l}\text { Seat belt } \\
\text { reminder }\end{array}$ & $\begin{array}{l}\text { Emniyet kemeri hatırlatıcı(sı) x20, } \\
\text { Emniyet kemeri hatırlatma sembolü x1, } \\
\text { Emniyet Kemeri Uyarıcısı x1. }\end{array}$ & $\begin{array}{l}\text { Emniyet Kemeri Hatırlatıcı(sı) x15, } \\
\text { Emniyet Kemeri İkazı x1, Emniyet } \\
\text { Kemeri Uyarıcısı x1, Emniyet Kemeri } \\
\text { İkaz Işı̆ı x1, Emniyet Kemeri Uyarısı } \\
\text { x1, Emniyet Kemeri Sensörü x1. }\end{array}$ & $\begin{array}{l}\text { Emniyet } \\
\text { kemeri uyarı } \\
\text { düzeni }\end{array}$ \\
\hline 10 & Generator & $\begin{array}{l}\text { Jeneratör x10, alternatör x5, dinamo x1, } \\
\text { batarya x2, akü x4. }\end{array}$ & $\begin{array}{l}\text { Akü x11, Dinamo x2, alternatör x3, } \\
\text { jeneratör x3, batarya x1. }\end{array}$ & $\begin{array}{l}\text { Jeneratör, } \\
\text { Altarnatör }\end{array}$ \\
\hline
\end{tabular}

Tablo 2: Kaynak Metin 2'den seçilen terimler ile A ve B Gruplarının çevirilerinde tespit edilen karşılıkları ve TDK terim sözlüğü referans alınarak belirlenen kabul edilebilir terim önerileri.

Tablo 2'de sunulan Kaynak Metin 2'ye dair verileri inceleyecek olursak, ilk terim olan "airbags" görece oldukça yaygın bir terim olup kimi zaman doğrudan aktarım yoluyla Türkçede de olduğu gibi kullanılabilmektedir. Çeviri önerilerinin tekil ya da çoğul isim çekimlerinin dışında her iki grup için de aynı oranda kabul edilebilir olduğunu görmekteyiz (A grubu 22 katılımcı da 22, B grubu 20 katılımcıda 20).

İkinci terim SRS aynı zamanda bir kısaltma olup açılımı "Supplementary Restrain System" yani TDK otomotiv terimleri sözlüğündeki karşllığı "Tamamlayıcı koruma düzeni” olarak verilmiştir. Ancak terim motorlu taşıtlarda emniyet kemerlerine ek olarak yolcu ya da sürücünün oturduğu koltuğa sabitlemek üzere yaralanma ve ölüm riskini düşürmeye yarayan güvenlik sistemidir. Bu bağlamda çeviri metinlerde "ek güvenlik" ya da "ilave kısıtlama" düzenekleri yorumları da kabul edilebilir sayılabilir. Böylece A grubu için 16 ve B grubu için de 12 çeviri birimi kabul edilebilir.

Üçüncü terim "diagnostic function" yine genel bir terim olmasına karşın A grubunda 11 ve B grubunda 8 çeviri birimi kabul edilebilir olarak nitelendirilmektedir. Her ne kadar çeviri metinlerde tam olarak karşılık ile benzeşmese de terim sözlüğündeki "arıza belirleme işlevi" için "tanı işlevi, hata ayıklama işlevi / fonksiyonu” gibi çeviri önerileri benzer anlam içermektedir.

Dördüncü terim "seat belt lock" için her iki grupta da ortalama olarak benzer sayıda kabul edilebilir çevirilere ulaşılmıştır. Beşinci terim "pretensioner" için iki grup arasında oldukça büyük bir fark gözlemlenmektedir. A grubunda 12, B grubunda ise 5 çeviri önerisi kabul edilebilir niteliktedir.

Altı ve yedinci terimler temel olarak birbirlerine yakın terimlerdir; "Front airbag" ve "Side impact airbag". Her ikisi de ilk terimde geçen "hava yastı̆̆ı"nın farklı türleridir. Sadece araç içinde farklı yerlerde bulunan "hava yastıklarını" nitelendirmektedir. Ne var ki, A grubunda altıncı terimin kabul edilebilir çeviri sayısı 21'den yedinci terim için 13'e düşerken B grubunda benzer biçimde 18'den 9'a düşmektedir. Bunun temel nedeni yedinci terimdeki "side impact" (yan darbe) kavramının tam anlamıyla anlaşılamamış olması sayılabilir.

Terim sözlüğünde karşllı̆̆ "Perde hava yastığı" olan sekizinci terim "inflatable curtain" terimi ise deney grubunda 14 kabul edilebilir çeviri birimine sahip iken kontrol grubu B'de bu rakam 2'ye düşmektedir.

Dokuzuncu terim "seat belt reminder" (emniyet kemeri hatırlatma / uyarı düzeni) A grubunda 20, B grubunda 15 kabul edilebilir çeviri birimine sahiptir. Son olarak "generator" teriminin A grubunda 16 kabul edilebilir çeviri birimine sahipken B grubunda ise sadece 6 kabul edilebilir çeviri birimi bulunmaktadır. 
Verileri genel anlamda yorumlamak gerekirse KM1 için A grubunda terimlerin en düşük kabul edilebilirlik oranına \%5o ile 7 ve 8'inci terimlerde (11'er adet) en yüksek ise yaklaşık olarak \%72 (16 adet) oranı ile 1, 9 ve 10’ncu terimler ve \%77 (17 adet) ile 3'üncü terimde ulaşılmıştır (bkz. Tablo 3). Diğer yandan aynı KM için kontrol grubu B'de ise en düşük kabul edilebilirlik oranına \%15 ile 10'uncu terimde ve en yüksek orana ise \%75 ile 2'inci terimde ulaşılmıştır (bkz. Tablo 4). Grupların genel ortalamasına bakıldığında ise A grubunda \%64,09 gibi bir orana ulaşılmıştır. B grubunun genel ortalaması ise \%48 olarak hesaplanmıştır.

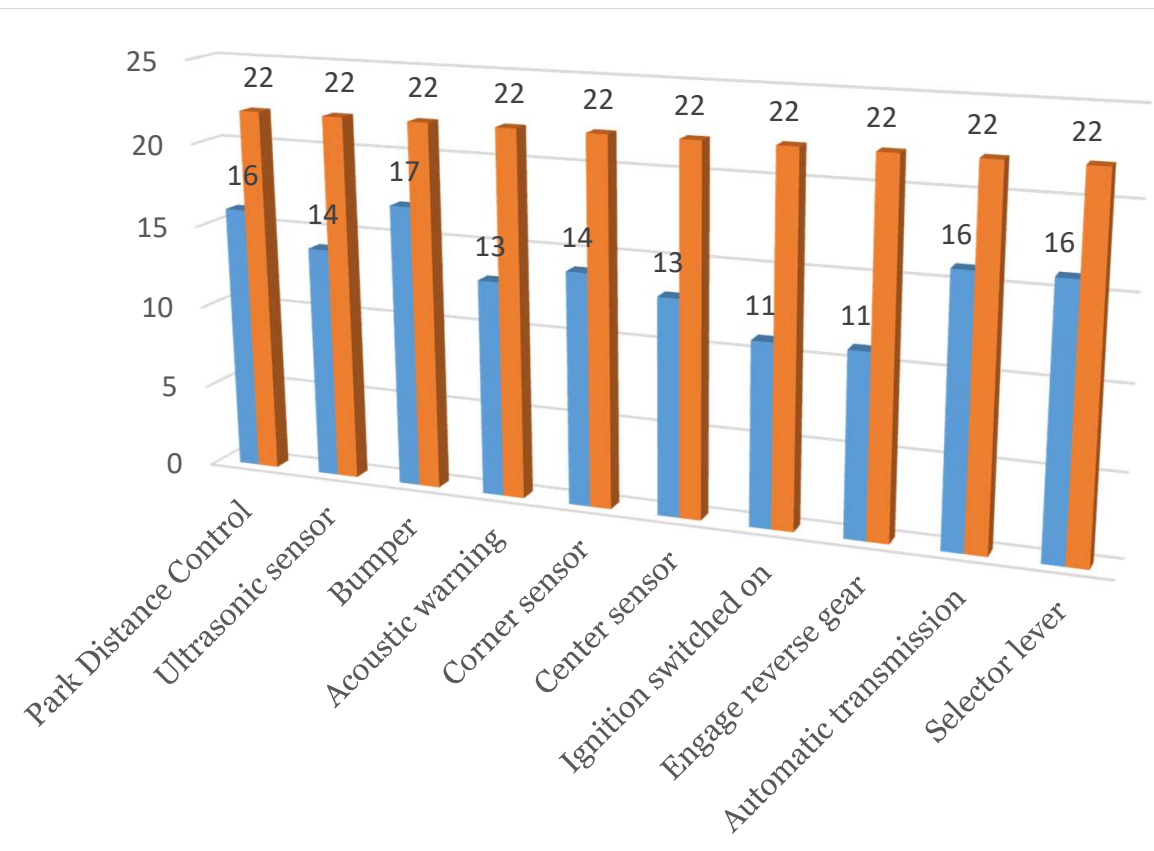

Tablo 3: KMı'in A grubu çevirilerindeki kabul edilebilir terimlerin katılımcı sayısına göre grafik dağılımı.

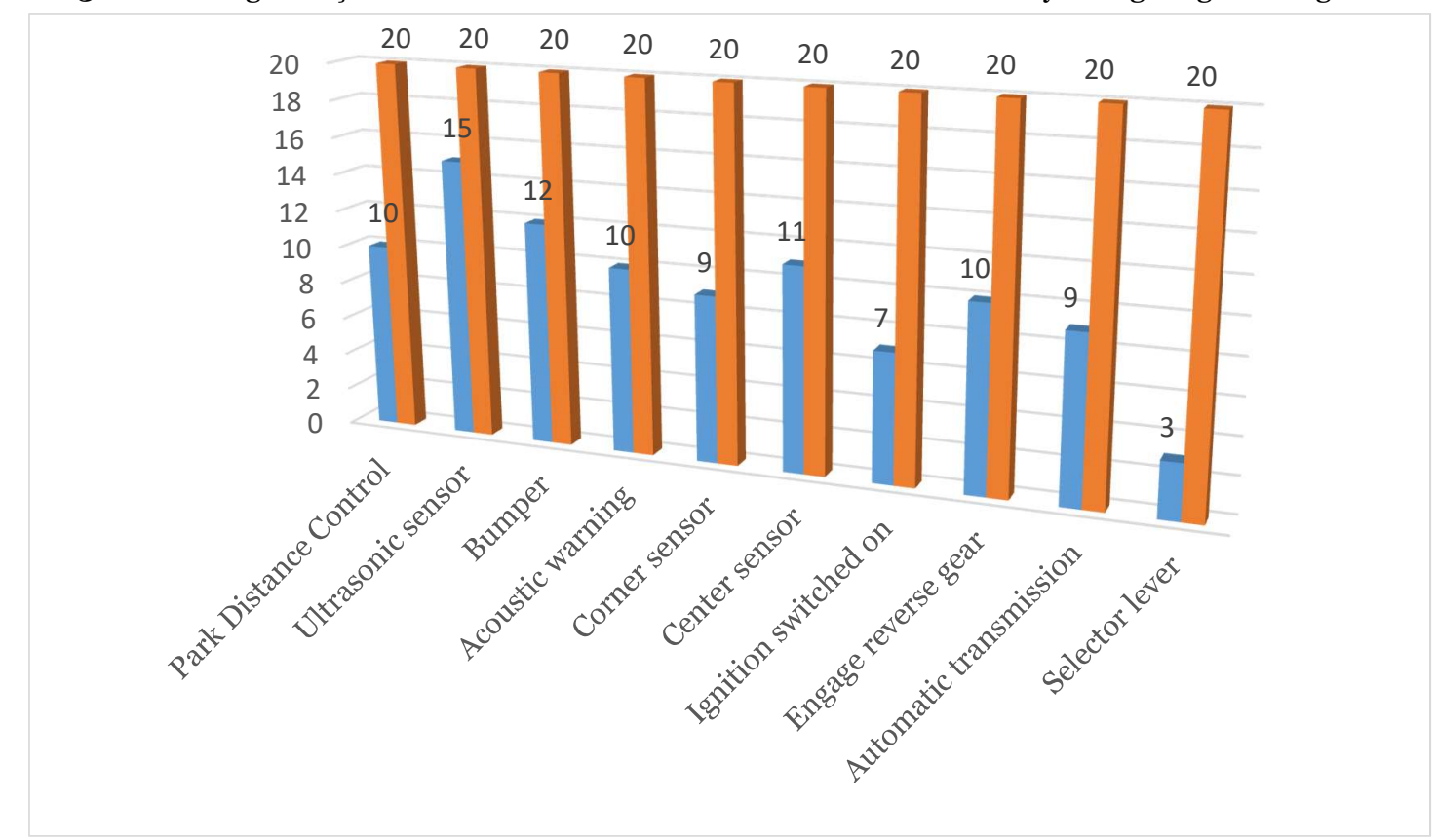

Tablo 4: KM1'in B grubu çevirilerindeki kabul edilebilir terimlerin katılımcı sayısına göre grafik dağılımı. 
Kaynak Metin için genel bir değerlendirme yapmak gerekirse A grubunda en düşük kabul edilebilirlik oranı \%50 ile 3'üncü terimde iken en yüksek oran \%10o ile 1'inci terimde bulunmaktadır (bkz. Tablo 5). Diğer yandan B grubunda ise en düşük oran \%10 ile 8'inci terimde olup en yüksek oran yine \%100 ile 1'inci terimdedir (bkz. Tablo 6). Genel ortalamalarına bakacak olursak A grubunda \%73,18 civarında yüksek bir kabul edilebilir terim oranına ulaşılmışken B grubunda bu oran \%55 olarak saptanmıştır.

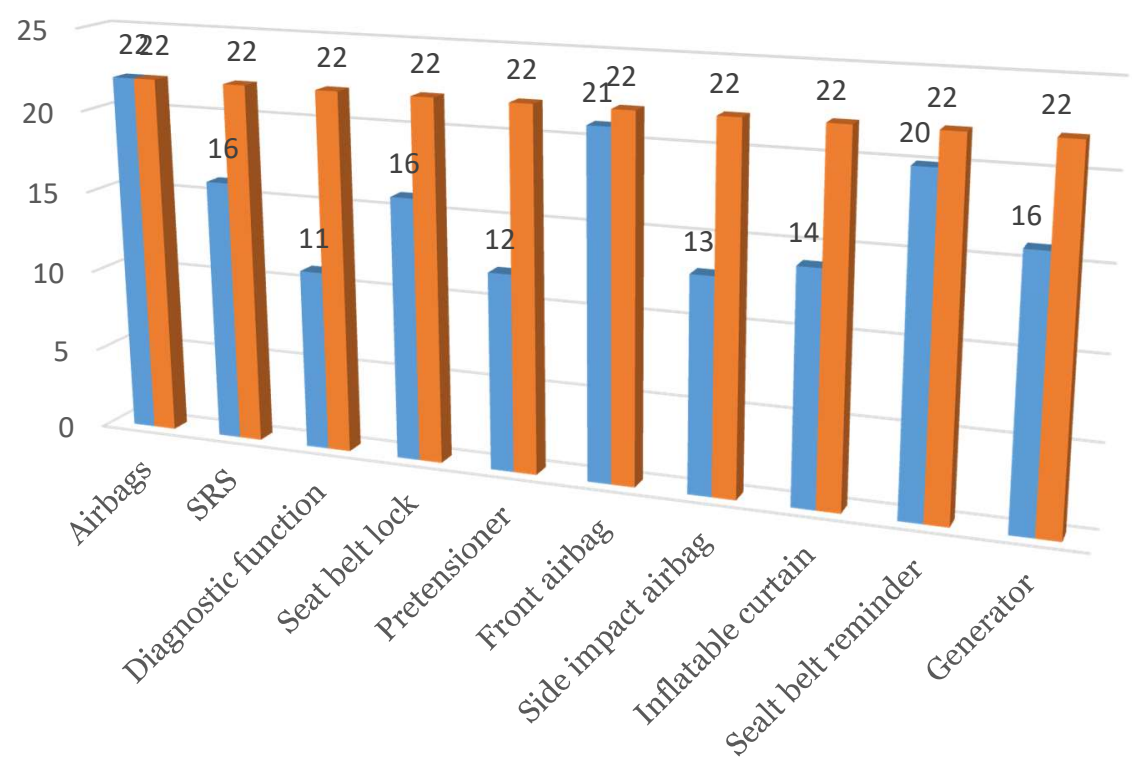

Tablo 5: KM2'in A grubu çevirilerindeki kabul edilebilir terimlerin katılımcı sayısına göre grafik dağılımı.

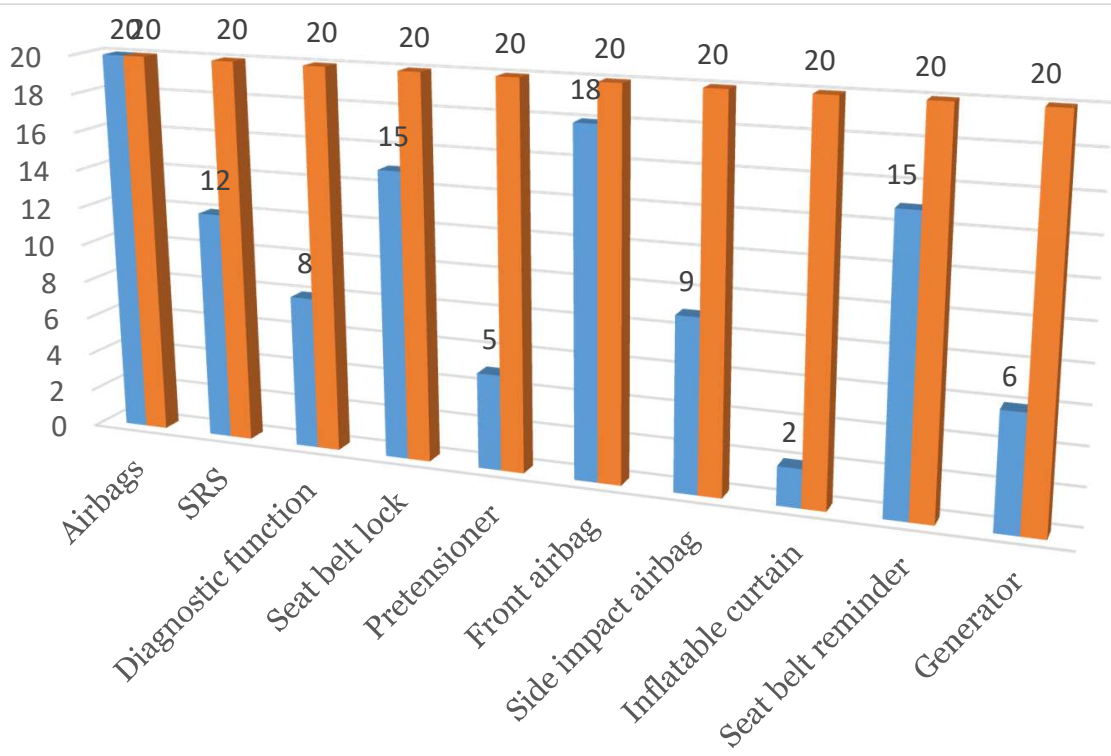

Tablo 6: KM2'in B grubu çevirilerindeki kabul edilebilir terimlerin katılımcı sayısına göre grafik dağılımı. 


\section{Sonuç}

Çeviri eğitimi programlarının en temel hedeflerinden biri Schäffner’in de vurguladığı üzere çeviri edincini geliştirmektir (2000). Lisans düzeyinde çeviri eğitiminde çeviri edincinin geliştirilmesine yönelik çalışmasında Schäffner ayrıca lisans düzeyinde bir çeviri programı için müfredat önerisinde bulunurken özellikle dil ve kültür edinci ile eş zamanlı olarak temel bir aktarım edincinin geliştirilmesinin mümkün olabileceğinden bahsetmektedir. Bununla paralel olarak çeviri eğitim programlarına uzmanlık alanı çevirisi, teknik çeviri ve özel alan çevirisi gibi farklı başlıklar altında derslerin dâhil edilmesi çevirmen adaylarının belirli alanlarda uzmanlaşmalarının önünü açabileceği şüphesiz bir gerçektir. Schäffner'in sunduğu örnek müfredat içeriğine ikinci ylldan itibaren terminolojinin de eklenmesi (a.g.e. 146) özellikle teknik çeviri ve uzmanlık alanı çevirisi gibi dersler için bütünleyici niteliktedir.

Teknik çeviri eğitiminde terminoloji ve terim çalışmalarının çeviri edincine etkilerinin incelendiği bu çalışmada Trakya Üniversitesi, Mütercim Tercümanlık Bölümü, İngilizce Mütercim-Tercümanlık programında 2018-2019 bahar yarıyılında kayıtlı üçüncü sınıf öğrencilerinden deney ve kontrol grubu olmak üzere iki grup oluşturulmuş ve bu gruplar arasında anlamlı ölçüde bir fark belirlenmiştir. Deney grubunun araştırmanın veri toplama sürecinden önceki dört hafta boyunca genellikle otomotiv sektöründe kullanılan kılavuz metinlerle çalışması, terim listeleri çıarılması ve söz konusu alanla ilgili broşürler üzerinde okumalar yapması KM1 ve KM2 metinlerinin çevirilerinde kontrol grubuna görece daha yüksek bir başarı göstermelerini etkilemiş olabilir. Diğer yandan kontrol grubunun aynı dört haftalık süre boyunca farklı alanlardan metinlerle çalışmış, otomotiv terimleri üzerine herhangi bir çalışma gerçekleştirmemiş olması KM1 ve KM2 metinlerinin çevirilerinde daha düşük bir başarı düzeyine sahip olmalarını açıklayabilir.

Araştırmada incelenen çeviri metinlerdeki görece kabul edilemeyen çeviri örneklerinin temel nedeni öncelikle eksik alan bilgisi ve terimceye hâkim olamamadan kaynaklanabilir. Dolayısıyla öğrencide çeviri alt edinçlerinden alan edinci ve uzmanlık alan edincinin henüz yeterli ölçüde gelişmediğinden bahsetmek mümkündür. Ancak çeviri bölümlerindeki öğrencilerin çeviri süreçlerine dair kararlarını inceleyen Araboğlu'nun da belirttiği gibi (2018, s. 309) çeviri doğası gereği kesin sinırları olmayan bir süreçtir ve bu süreçte öğrencilere sadece alan ya da uzmanlık alanı edinci edindirmek yeterli olmayacaktır. Yine Araboğlu'na göre öğrencilerin temel çeviri gerçekleri ve çevirinin belirli bir bağlam içerisinde gerçekleşen bir yorumlama işi olduğu bilincini de edinmeleri gerekmektedir. Ayrıca bu bilinç kısa sürede edinilecek bir şey değildir aksine çevirmen adayının diğer derslerinde edindiği teorik ve uygulama becerileri ile paralel olarak eğitimi sürecinde desteklenmesi beklenebilir. Teknik çeviri gibi görece uzmanlık alanı bilgisi ya da özel alan bilgisi gerektirebilen derslerin içeriğine ya da genel eğitim müfredatına bu çalışmada vurgulanan terminoloji etmenin yanı sıra bu bilinci edinecekleri olanakları sağlamak ve kullanılacak metinlerin bağlamını da bu doğrultuda çeşitlendirmek gerekir.

Sonuç olarak uzmanlık alanı ya da özel alan çevirisi gibi derslerin yanı sıra teknik çeviri derslerinde belirli bir düzeyde alan terim bilgisinin edinilmesi ile öğrencilerin çeviri alt edinçlerinden alan edinci ve uzmanlık alanı edincinde azımsanmayacak ölçüde bir gelişmenin gerçekleştiği görülmektedir. Bu sebeple terminolojinin ya ayrı bir ders çerçevesinde çeviri eğitimi lisans düzeyi programlarına dâhil edilmesi ya da teknik çeviri, özel alan çevirisi ve uzmanlık alanı çevirisi gibi derslerin içeriğine dâhil edilmesi önerilebilir. 


\section{Kaynakça}

Acar, E., \& Korkmaz, İ. (2017). EMT Tarafindan Belirlenen Çeviri Edinci Modelinin Lisans Düzeyindeki Mütercim Tercümanlık Öğrencilerinde İncelenmesi: Trakya Üniversitesi Örneği. Eurasian Conference on Language and Social Sciences, May 22 - 24 2017, (s. 444-452). Alanya, Turkey.

Aixela, J. (2004). The Study of Technical and Scientific Translation: An Examination of its Historical Development. (S. J. Publishing, Dü.) Journal of Specialised Translation, 1(1), 29-49. Mart 5, 2019 tarihinde alındı

Akalın, R. (2016). Akademik Çeviri Eğitimi Açısından Çeviri Edinci Kavramı ve İçerimleri. Diyalog(2), $56-65$.

Araboğlu, A. (2018). Çeviri Sürecinde Kendi Kararlarını Verebilen Çeviri Öğrencilerine Yönelik Bir Uygulama Örneği. RumeliDE Dil ve Edebiyat Araştırmaları Dergisi, 307-315.

Byrne, J. (2006). Technical Translation: Usability Strategies for Translating Technical Documentation. Netherlands: Springer.

Durukan , E., \& Çelikay, K. (2018). Çeviri Edinci Kavramına Yönelik Kapsayıcı Bir Tanım Önerisi. $\begin{array}{llll}\text { Turkish } & \text { Studies, } & \text { 13/12(Spring } & \text { 161-176. }\end{array}$ doi:http://dx.doi.org/10.7827/TurkishStudies.13601

Hervey, S., \& Higgins, I. (2002). Thinking French Translation: A Course in Translation Method: French to English. Londra \& New York: Routledge.

İmer, K., Kocaman, A., \& Özsoy, A. (2013). Dilbilim Sözlüğü. İstanbul: Boğaziç Üniversitesi Yayınevi.

Korkmaz, İ. (2017). Teknik Metinlerde İşlevsellik: Kullanma Kılavuzlarının Çevirileri. Ankara: Gece.

Newmark, P. (1988). A Textbook of Translation. Hernel Hemstead, UK: Prentice Hall .

PACTE Research Group. (2000). Acquiring Translation Competence: Hypotheses and Methodological Problems in a Research Project. A. Beeby, D. Ensinger, \& M. Presas (Dü) içinde, Investigating Translation: Selected papers from the 4th International Congress on Translation, Barcelona, 1998 (s. 99-106). Amsterdam: John Benjamins.

Sager, J. (2001). Terminology. M. Baker (Dü.) içinde, Routledge Encyclopedia of Translation Studies (s. 259). Londra \& New York: Routledge.

Schäffner , C. (2000). Running Before Walking? Designing a Translation Programme at Undergraduate Level. C. Schäffner , \& B. Adab (Dü) içinde, Developing Translation Competence (s. 143-156). Amsterdam / Philadelphia: John Benjamins Publishing Company.

TDK. (2011). Türkçe Sözlük, 11. Baskl. Ankara: Türk Dil Kurumu.

Toury, G. (2008). The Nature and Role of Norms in Translation. L. Venuti (Dü.) içinde, The Translation Studies Reader (s. 205-218). New York: Routledge Taylor and Francis Group.

Vardar, B. (2002). Açıklamalı Dilbilim Terimleri Sözlüğü . İstanbul: Multilingual.

Yüce, N. (2013). Otomotiv ve Hafif Araç Terimleri Sözlüğü. Ankara: Türk Dil Kurumu. 